\title{
Impact of Gender in the Perception of Administrative Burdens among Young Entrepreneurs - Evidence from Slovakia
}

- Ključnikov Aleksandr, Sobeková Majková Monika

\begin{abstract}
Excessive bureaucracy, administration, and frequent legislative changes belong among the common factors that discourage people from entering the world of business. The main objective of this paper is to introduce scientific evidence that gender is one of the factors with a significant impact on the management of a company's administrative activities and on the perception of such administrative burdens as bureaucracy and, often, tax and legislative changes as one of the barriers to young entrepreneurs in the Slovak business environment. On the basis of the research data that was obtained, we wish to confirm that gender has a statistically significant impact on the amount of time spent fulfilling the administrative and bureaucratic requirements among young entrepreneurs in Slovakia. We consider the findings of the research on administrative burdens to be important because of the assumption that excessive bureaucracy could have a negative impact on the competitiveness of every economy. The paper uses data from research carried out in Slovakia in cooperation with the Association of Young Entrepreneurs of Slovakia. Verification or rejection of alternative working hypothesis was realized through the statistical method of Pearson's chi-square test. Our results bring the following findings: young men and women consider different areas of the bureaucracy to be excessive; female entrepreneurs spend more time watching the changes in legislation affecting the business environment, and females spend almost twice as much time on administrative activities related to business in comparison to their male counterparts. These findings are confirmed by the statistical evidence.
\end{abstract}

Keywords: business, bureaucracy, administrative burden, young entrepreneurs, male and female entrepreneurs, SME

JEL Classification: G11, G32

\section{INTRODUCTION}

Such terms as bureaucracy, officialdom, or red tape are used to describe the type of administrative burden that has a negative influence on business. Despite the fact that small and mediumsized enterprises are a key element of the market economy, their role is often underestimated and they are quite vulnerable and overloaded by bureaucracy.

Although the majority of entrepreneurs complain about huge administration and bureaucracy, and consider them to be among the biggest barriers in the Slovak business environment (Jakubec et al., 2012), published data from the international survey Paying Taxes 2016 (PWC, 2016) indicates that the situation is getting better. The data from this study indicates that while Slovakia has made significant progress in the tax field and is placed in 73rd position out of 189 countries 
in terms of how easy it is to pay taxes (a significant upgrade from 135th position in 2011), the level of the administrative burden for Slovak SMEs still remains at a substantial level. Slovak entrepreneurs have to spend 188 hours per year (207 in 2011) to comply with the tax norms, and have to make approximately 10 tax payments per year $(20$ in 2011). Slovakia has a total tax rate of $51.2 \%$, which is above the world average of $40.4 \%$, but is below the average in terms of the total number of tax payments and the time burden in the tax field.

We should also consider the fact that besides the tax legislation requirements, entrepreneurs have to fulfil the administrative requirements of many other regulatory institutions, such as health and social insurance companies, government authorities in the field of hygiene, safety regulations, the state statistical office, and other authorities.

The main objective of this paper is to show scientific evidence that gender is one of the factors with a significant impact on the management of a company's administrative activities, on the perception of such administrative burdens as bureaucracy and, often, tax and legislative changes as one of the barriers to young entrepreneurs in the Slovak business environment. On the basis of the data that was obtained we tried to identify the existence of differences between young men and women in what they consider significant obstacles to entrepreneurship and in the amount of time they spend watching the legislative changes as a part of their process of self-education, and also gender differences in the level of sensitivity to bureaucracy among young entrepreneurs. A case study of the statistical differences in performing administrative duties between women and men was realized in the chosen region of the European Union - in Slovakia. The side objective was to analyze the gender differences between entrepreneurs in terms of the intensity with which they watched legislative changes and the number of hours spent on administrative activities.

\section{LITERATURE RESEARCH AND ADMINISTRATIVE BURDEN FOR BUSINESS IN SLOVAKIA}

Recent scientific literature suggests that heavy administrative burdens have a negative impact on competition and the growth of small businesses. Small and medium-sized enterprises (SME) have a lot of problems with survival, not only in Slovakia, but basically all over the world, and difficult administrative burdens make their life even more complicated. In this part of the article we would like to prove that administrative burdens or bureaucracy are often affected by the business environment of small and medium-sized enterprises. The subsequent literature review and studies declare that administrative burdens have a negative impact on the economy and the business environment.

Using the analysis of the data collected by the World Bank, Djankov et al. (2008) confirm the truthfulness of the above statement. Bianco and Bripi (2010) analyzed the influence of administrative burdens on selected Italian regions on the basis of the data from the Doing Business report. Despite the improvements made over the last ten years, the situation in this country is still very complicated and there are great differences among regions. According to these authors, administrative burdens worsen the business environment and make it more complicated.

Královič, Fetisovová, and Nagy (2008) see the reduction of the administrative burdens for SMEs in Slovakia as one of the methods of support which may intensify the development of this group 
of enterprises. Djankov et al. (2006) provide information about the negative correlation between the growth of GDP per capita in 135 countries and the aggregate index of business regulations. Barone and Cigano (2008) found that lower regulation translates into faster growth of value added, productivity, and exports. Ključnikov and Junger (2014) declare the complexity of the business regulations and administrative burdens to be a significant barrier to the inflow of foreign direct investment and the development of the local SMEs in Belarus. Krasniqi (2007) stated that the growth of SMEs is reduced by the existence of such environmental barriers to business as their tax burden, unfair competition, and inadequate financing.

Belas et al. (2013) considers administrative burdens in Slovakia to be one of the most significant problems for small and medium-sized enterprises. Administrative burdens are often accompanied by the difficulties in obtaining of financial resources and small capital power. Arnold et al. (2008) observed the productivity performance in OECD during 15 years, and found that strict regulation of services slowed down their growth. Petr (2010) highlights the potential increase in business risk in relation to the increased administrative burden. According to Bianci and Bripi (2010) business regulation influences entrepreneurs in following areas: starting a business, hiring and firing workers, registering property, getting bank credit, protecting equity investors, enforcing contracts in courts and also closing a business and bankruptcy.

Here are some other examples of administrative burdens:

in registering property: Simple, cheap and fast procedures of property registration lead to easier access to formal credit, increase the land value, create greater investment opportunities (Field, 2006) and provide significant bene fits for the whole economy (Deininger, 2003);

in closing business: Bankruptcy procedures are also the form of administrative burden. Efficient bankruptcy procedures ensure higher probability of survival for firms in business problems while also guaranteeing higher recovery rates for creditors and hence greater ex ante credit availability (White \& Berkowitz, 2004);

in enforcing contracts: An excessive length of trials has a negative impact on credit availability, company's entry and size (Jappelli et al, 2005).

The impact of the gender of the entrepreneur on the different aspects of business is a widely discussed factor. Many researchers examine the impact of gender on the perception of different business aspects, and the results are contradictory. For instance Garwe and Fatoki (2012) state that gender has a significant impact on SME finance. The reason for this issue is hidden in the women's nature, they are less self confident and as a result more discouraged from bank financing than men due to the reason that they are in fear of rejection due to the lack of education and lack of personal assets or collateral. According to Belás et al. (2015b) women to a lesser extent perceive the intensity of influence of the financial risk on the business environment, but are surprisingly more confident in their ability to properly manage financial risks of their company.

Gramage (2013) presents the opposite opinion and negates the influence of the gender as a determinant of an access to business finance. Freel et al. (2010) and Mama and Ewoudou (2010) also declare that gender is not a significant factor in access to credit loan. According to the other research team, women more intensively perceive that the intensity of business risks grew during the crisis (Belás, 2015a). 
Roper and Scott (2009) and Mijid (2009) identified that gender has a substantial influence on the demand for and availability of credit, which is interconnected with the way of monitoring the legislative changes and the quality of the fulfilment of the administrative requirements. Constantinidis et al. (2006) agrees with opinion gender is a significant factor. He found out differences in access to finance of male and female owners of venture capital companies.

Women tend to perceive ethical standards and support philanthropic projects of their banks more than men (Paulík et al, 2015). Sobeková - Majková et al. (2014) and Jakubec et al. (2012) present gender as statistically significant factor in the segment of young entrepreneurs. Irwin and Scott (2010) presented the findings about the impact of gender on the access to bank finance of UK SMEs. They researched that men are more financially constrained than women.

What about the situation in Slovakia? According to the NADSME (2006) Slovak business authorities considered the following problems as the main problems in business in Slovakia:

- bureaucracy of the officials at almost every level of government;

- long processing time;

- obligation to submit different types of confirmation of the facts, that are already known for the state authorities;

- obligation to submit a number of statistical reports.

Heavy administrative burdens in Slovakia were also discussed by other authors. Fetisovová et al (2009), Sobeková Majková (2008, 2011), Jakubec et al. (2012), Belas et al. (2013), Ključnikov and Jünger (2014) present heavy administrative burdens as a factor which worsens business conditions in the country. Slovak companies have substantial problems with weak capital power, lack of capital and administrative obstacles. Slovak trade and industry chamber (SOPK, 2009, 2010) in its own research reflects that administrative burdens related to the processes of starting and closing the business, and related to regular business activities are still significant.

Since 2006 the situation in Slovakia has changed and the government is trying to reduce administrative burdens. Slovakia, like others EU countries, committed to reduce administrative burdens on business by $25 \%$ by the end of 2012. This objective is documented in the Action Programme for reducing burdens in the Slovak republic 2007 - 2012. Ministry of Economy established 2 stages of measurement of administrative burdens. The first stage included the analysis, revealing that individuals had 246 information obligations and legal persons had 237 information obligations. The cost of the administrative burden on business arising from 48 legislative acts was estimated at the value of 91 million euro in total, administrative costs had the estimated cost of 992 million euro. The highest administrative costs were caused by the regulations of the Ministry of Finance and the greatest administrative burden was caused by the regulations of the Ministry of Health (Ministry of Economy, 2007).

72 laws and consequent legal norms were mapped during both stages of the process, and as a result approximately 1400 information obligations were identified. Estimated burden of Slovak law was estimated with the value of 659 million euro ( $1 \%$ of GDP), and the estimation of total administration costs was around 1.98 billion euro (3\% of GDP). On the basis of the proposed measures the state managed to degrade burden in the total value of 64.5 million euro, that pre- 
sented $60 \%$ of burden measured during the first two stages in the period from 2009 to 2011 in the absolute amount 109 million euro (Ministry of Economy, 2007).

The changes proposed for the current accounting law, which was marked as the most problematic law act in Slovakia, should have the positive impact on approximately $60 \%$ of entrepreneurs. The main ideas of the proposal are the decreasing of the number of pages of accounting statements from 45 to 8 , removal of the obligation to have price evidence according to the price law and implementation of the possibility to make accruals for small companies. In case that these proposals will be implemented, the total number of the documents that Slovak entrepreneurs have to fill every year will be reduced by almost 2.6 million pages.

\section{METHODOLOGY OF RESEARCH}

In cooperation with the Association of Young Entrepreneurs in Slovakia the national research about the obstacles in starting business was performed in 2012 in Slovakia. The data were collected by the prepared online questionnaire, so the choice of respondents was stochastic. We divided the respondents into two groups - the first one included young people who had a potential to become the entrepreneur, and the second group contained young entrepreneurs up to 34 years old.

Online questionnaire was filled by 1232 respondents, 324 of them were young entrepreneurs, 908 responded were not doing business. The results, published in this paper are related only to the impact of gender on the perception of administrative burden.

Table 1 presents characteristics of the basic data set in relation to the type of the enterprise. Young entrepreneurs up to 34 years old made up one third from the total number of individual entrepreneurs. Due to the fact that other legal types of the enterprises than individual entrepreneurs can be founded by more than one person and the founders can have different age, we are not able to identify the number of companies with young owners among them.

Tab. 1 - Numbers of Entrepreneurs by the Legal Form and Size. Source: Company register of Statistic Bureau, 2010, processed by NADSME

\begin{tabular}{|c|c|c|c|c|}
\hline \multirow[t]{2}{*}{ Legal Form } & \multirow[t]{2}{*}{ Total } & \multirow{2}{*}{$\begin{array}{l}\text { Share on the } \\
\text { total number of } \\
\text { companies in } \%\end{array}$} & \multicolumn{2}{|c|}{$\begin{array}{c}\text { Entrepreneurs up to } \\
34 \text { years old }\end{array}$} \\
\hline & & & absolutely & in $\%$ \\
\hline Individuals entrepreneurs & 410308 & 74.2 & 119175 & 29.0 \\
\hline tradesman & 384202 & 69.4 & 114653 & 29.8 \\
\hline free enterprise & 18378 & 3.3 & 3855 & 21.0 \\
\hline self employed farmer & 7728 & 1.4 & 667 & 8.6 \\
\hline Legal entities & 143001 & 25.8 & & \\
\hline micro companies (0-9 emp.) & 130144 & 23.5 & & \\
\hline small companies (10-49 emp.) & 9549 & 1.7 & & \\
\hline
\end{tabular}




\begin{tabular}{|l|c|c|}
\hline middle companies (50-249 emp.) & 2724 & 0.5 \\
\hline large companies (250 and + emp.) & 584 & 0.1 \\
\hline Total number of business units & 553309 & 100.0 \\
\hline - SME from total & 552725 & \multirow{2}{|}{} \\
\cline { 1 - 2 } - SME form total in \% & 99.9 & \\
\cline { 1 - 2 }
\end{tabular}

Basic data set and our selection file have significant similarities, especially in relation to gender. According to NADSME (National Agency for Development of Small and Medium size Enterprises) the data in the basic data set contains $76.70 \%$ male and $23.30 \%$ female members, while our selection file contains $64.2 \%$ male and $35.80 \%$ female entrepreneurs.

Table 2 presents the comparison of the regional structure of the basic data set and the selected sample. The last column presents the difference between the selection and the basic data set for the selected region, where the differences are below $7 \%$ in each category.

Tab. 2 - Regional Structure Comparison of Basic and Selection File. Source: NADSME

\begin{tabular}{|l|c|c|c|c|}
\hline \multirow{2}{*}{ Region } & \multicolumn{2}{|c|}{ Selected sample } & Basic data set & Difference \\
\cline { 2 - 5 } & $\begin{array}{c}\text { count } \\
\text { of respondents }\end{array}$ & \% respondents & \% companies & \% companies \\
\hline Bratislava & 92 & 28.40 & 34.70 & -6.30 \\
\hline Žilina & 52 & 16.05 & 9.40 & +6.65 \\
\hline Prešov & 38 & 11.73 & 9.20 & +2.53 \\
\hline Košice & 37 & 11.42 & 10.30 & +1.12 \\
\hline Trenčín & 34 & 10.49 & 8.30 & +2.29 \\
\hline Banská Bystrica & 31 & 9.57 & 8.80 & +0.77 \\
\hline Nitria & 21 & 6.48 & 10.00 & -3.52 \\
\hline Trnava & 19 & 5.86 & 9.20 & -3.34 \\
\hline
\end{tabular}

\section{a. Analysis of the results}

Our research involved such instruments as the tools of descriptive statistics (averages and percentage), Microsoft Excel (Office 2007) software as an important tool for data analysis due to its possibilities in data processing using pivot tables, the methods of comparison and deduction in data analysis. The statistical method of Pearson's chi-square at the significance level of $5 \%$ was applied by using the statistical software $\mathrm{R}$ for the verification of the existence of the statistically significant dependences and differences between the selected factors. If the calculated p-value was lower than 5\%, the null hypothesis was rejected, and the alternative hypothesis was adopted. Due to the length limitations the article presents the results of some selected problems.

Chi-squared analysis is a valuable statistical method also referred as an $\chi^{2}$ test is the statistical hypothesis test where the sampling distribution of the test statistic is a chi-squared distribution, identifying whether the null hypothesis is true or not, with the selected level of probability. 
Value of the test-statistic is:

$$
\mathrm{X}^{2} \sum_{\mathrm{i}=1}^{\mathrm{n}} \frac{\left(\mathrm{O}_{\mathrm{i}}-\mathrm{E}_{\mathrm{i}}\right)^{2}}{\mathrm{E}_{\mathrm{i}}}
$$

where:

$\chi^{2}$ - Pearson's cumulative test statistic

$\mathrm{O}_{i}-$ the number of observation

$E_{i}$ - expected (theoretical) frequency of type $i$, asserted by the null hypothesis that the fraction of type

$n$ - the number of cells in the table

Chi-squared distribution has a specific parameter $\mathrm{k}$, which is a positive integer that specifies the number of degrees of freedom. This method is used to determine the probability with which the difference between the expected and observed values was randomly found.

We calculate the chi-square statistic by the following steps:

1. Subtract the corresponding expected number $(O-E)$ for each observed number in the table.

2. Square the difference $\left[\left(O_{i}-E_{i}\right)\right]$.

3. Divide the squares obtained for each cell in the table by the expected number for that cell $\left[(O-E)^{2} / E\right]$.

4. Sum all the values for $\left(O_{i}-E_{i}\right)^{2} / E_{i}$ This is the chi square statistic.

According to the results of Slovak Statistic Bureau in 2011 the share of the female entrepreneurs on the total number of the entrepreneurs reached the level of $27.7 \%$. Women entrepreneurs were mostly engaged in the field of services. The share of female entrepreneurs in 2011 was significantly higher, than in 2000, where the percentage of female entrepreneurs was reached the level of $25 \%$. It is evident, that the share of women on the total number of entrepreneurs is increasing and therefore their role in the business environment becomes more and more important. The increasing importance of this group of entrepreneurs was one of the reasons why we decided to examine their attitude to the bureaucracy and administration, and to identify whether they attitude is somehow different from the male counterparts. Our research had several partial aims. We wanted to answer the questions whether female entrepreneurs spend different amount of time with administrative activities in comparison to male counterparts, and whether they spend more time watching legislative changes than men. Recent researches dealing with the problematics of gender in relation to business revealed, that that women are more cautious in business, that they start to make business with smaller capital and that they are less courageous in comparison to men - these indicators have been identified as distinctive between men and women entrepreneurs. Women might have different behaviour than men do, but their importance for the economy is increasing and the European Union tries to support them in doing business. The arguments were constructed according to the experience and estimations of the research team. 


\section{b. Working alternative hypotheses}

Administrative burdens are created by many factors, such as bureaucracy, administrative activities and often legislative changes and changes in business environment. To investigate the impact of gender on company's administrative activities and perception of administrative burdens as bureaucracy and often legislative and tax changes, we defined three alternative working hypotheses (H1 - H3), the accuracy of which was verified by the statistical methods. Null hypotheses assuming there are no statistically verifiable differences between the observed groups were supplementing the alternative hypotheses.

Null hypothesis: $\pi_{1}=\pi_{2}$ so $\pi_{1}-\pi_{2}=0$

Alternative hypothesis: $\pi_{1}-\pi_{2} \neq 0$

In order to fulfil the aim of the article we set three working hypothesis in relation to the attitude of young entrepreneurs to the administrative burdens as bureaucracy, administrative activities and often tax and legislative changes:

Hypothesis 1: There are statistically significant differences in the perception of bureaucracy resp. administrative burdens between young male and female entrepreneurs in chosen areas.

Hypothesis 2: Young women entrepreneurs spend more time with monitoring the changes of legislation, affecting the business environment, than men. The possible reason might be that women are more cautious, diligent, prudent and responsible in fulfilling the administrative obligations.

Hypothesis 3: Young women entrepreneurs spend more time with administrative activities than men. For the same possible reason as in H2.

The aim of the article is to bring statistical evidence that gender is important factor with significant impact on attitudes of entrepreneurs to such administrative burdens as bureaucracy in business environment and often changes in tax and legislative. Due to different gender characteristics, that may reflect in the different attitude to the administrative requirements, and that may originate from the different level of sensitivity and cautiousness, we assume that male and female entrepreneurs have different habits and behaviour. According to the current statistical data in relation to gender women entrepreneurs represent almost one third of all entrepreneurs in Slovakia, and this share increased by 3\% during the last 10 years. Knowledge of the specifics of behaviour of each of these two groups of entrepreneurs may allow us to predict the changes of behaviour invoked by the changes of legislative norms and bureaucracy in business environment.

At first we investigated bureaucracy in business environment as an administrative burden. Our research observations included the total number of 324 young entrepreneurs -208 men and 116 women. Table 3 presents partial results of the answers to the question "In which area of business do you perceive the highest level of bureaucracy". Respondents were able to choose none, one or more options out of seven possibilities. Five most marked possibilities are presented in Table 3. Results of statistical calculation are conformal with the analysis of percentage. Calculated value 
of chi square was $\chi^{2} 0.05$ with $4 \mathrm{dgf}=10.0591$. Our hypothesis 1 was confirmed with the probability of $95 \%$ probability. These data confirm with results of such authors as Belás et al. (2015b), Garwe and Fatoki (2012), Sobeková - Majková et al. (2014), Jakubec et al. (2012) and Irwin and Scott (2010) that consider gender for a relevant factor affecting entrepreneurship.

Tab. 3 - The most important areas of bureaucracy according to gender. Source: own processing

\begin{tabular}{|l|c|c|}
\hline In which area do you perceive the highest level of bureaucracy & Men & Women \\
\hline Obtaining government benefits and subsidies & $69.71 \%$ & $65.52 \%$ \\
\hline Administrative requirements & $62.50 \%$ & $44.83 \%$ \\
\hline Procurement & $40.87 \%$ & $18.97 \%$ \\
\hline Employment & $33.17 \%$ & $22.41 \%$ \\
\hline Company's formation & $27.88 \%$ & $12.07 \%$ \\
\hline
\end{tabular}

Table 4 presents the results of the research in relation to the amount of time averagely spent by monitoring the changes of legislation, affecting the business environment. The results of percentage analysis show that women spend more time with this process. While only $11.54 \%$ men spend 5 to 10 hours per week by watching the legislative changes, twice as big group $(22.41 \%)$ of their female counterparts devotes the same amount of time to this activity. It is interesting that a huge group of men (25\%) but only a small group of women $(10.34 \%)$ do not watch the legislative changes at all. The value of chi square was high $20.35\left(\chi^{2}=20.35>13.3=\chi^{2} 0.01\right.$ with 4 dgf $)$ and that means there is a statistically significant difference between the behaviour of men and women in relation to watching the changes of legislation, affecting the business environment. Hypothesis 2 was verified at the level of significance of $1 \%$. Analysed data were included the options I don't know and neither.

Tab. 4 - An average time spent by watching the changes of legislation, affecting business environment. Source: own processing

\begin{tabular}{|l|c|c|}
\hline $\begin{array}{l}\text { How much time do you averagely spend by watching the changes of } \\
\text { legislation, affecting business environment }\end{array}$ & Men & Women \\
\hline more than 10 hours per month & $5.77 \%$ & $13.79 \%$ \\
\hline 5 - 10 hours per month & $11.54 \%$ & $22.41 \%$ \\
\hline less than 5 hours per month & $35.58 \%$ & $29.31 \%$ \\
\hline I don't know & $22.12 \%$ & $24.14 \%$ \\
\hline neither & $25.00 \%$ & $10.34 \%$ \\
\hline
\end{tabular}

Belás et al. (2015b) declare in their study that women perceive the intensity of the influence of financial risk on the business environment to a lesser extent, but they are, surprisingly, more confident in their ability to manage the financial risks of their company properly. Their confidence in managing financial risk could also be influenced by the fact they are better informed about changes in legislation and the business environment, as we discovered. It means they are better prepared theoretically and so they could be more confident in managing financial risks. 
We also agree with Garwe and Fatoki (2012), who state that gender has a significant impact on SME finance. They see the reason for different behaviour as being hidden in women's nature. According to these authors, women are less self-confident and as a result more discouraged from bank financing than men. But we think that this feature of women forces them to spend more time watching changes in the legislation and the business environment.

A similar view that gender has a significant impact on business decisions is also presented by such authors as Sobeková-Majková et al. (2014), Jakubec et al. (2012), and Irwin and Scott (2010).

Table 5 shows the results related to the third hypothesis. Data from percentage analysis reveals the fact that women spend almost twice as more time on administrative activities related to business as men. The chi-square value is $10.717\left(\chi^{2}=10.717>9.5=\chi^{2}{ }_{0.05}\right.$ with 4 dgf. $)$, which indicates that there are statistically significant differences between men and women and bypothesis 3 was verified at the $5 \%$ level of significance.

Tab. 5 - The average time per month spent managing administrative activities. Source: authors' own processing

\begin{tabular}{|l|c|c|}
\hline $\begin{array}{l}\text { How much time do you spend on managing administrative activities } \\
\text { related to your business? }\end{array}$ & Men & Women \\
\hline more than $20 \%$ of my working time & $18.27 \%$ & $18.10 \%$ \\
\hline $11-20 \%$ of my working time & $15.87 \%$ & $26.72 \%$ \\
\hline $6-10 \%$ of my working time & $21.15 \%$ & $20.69 \%$ \\
\hline less than $5 \%$ of my working time & $31.25 \%$ & $17.24 \%$ \\
\hline I don't know & $13.46 \%$ & $17.24 \%$ \\
\hline
\end{tabular}

Our research revealed statistically significant differences in the perception of such administrative burdens as bureaucracy, administrative activities, and tax and legislative changes between young male and female entrepreneurs. The following statements were verified by the statistical method of Pearson's chi-square and also by percentage analysis:

1. There are statistically significant differences between young male and female entrepreneurs in the perception of bureaucracy in the selected areas of business.

2. Women spend more time watching changes in the legislation affecting the business environment in comparison to men. On average women spend twice as much time watching legislative changes as men, so their attitude to self-education in business is quite different in comparison to men.

3. Young female entrepreneurs spend almost twice as much time on average on managing administrative activities as men.

The findings presented in this article document the fact that gender significantly influences the behaviour of entrepreneurs. As women presented a higher level of sensitivity to bureaucracy, we can assume that a worsening situation in the field of administrative burdens and bureaucracy will have a more significant negative influence on female entrepreneurs, because they react more intensively, spend more time on administrative activities, and are substantially more interested 
in legislative changes. Men have a laxer attitude to their administrative and legislative duties and so they spend less time on administrative activities.

\section{CONCLUSION}

Djankov et al. (2008), Bianco and Bripi (2010), Ključnikov and Junger (2014), Krasniqi (2007), Belas et al. (2013), Arnold et al. (2008), Jappelli et al. (2005), Jakubec et al. (2012), SobekováMajková et al. (2014), etc. declare that such administrative burdens as bureaucracy in business and, often, tax and legislative changes are substantial problems for companies all over the world. These burdens are considered a barrier to countries' economic growth, their competitiveness, and the development of SMEs. Every Slovak government promises a reduction in bureaucracy and administrative burdens, but they still have a problem putting into practice laws related to business (e.g. tax law). The country's legislation in this area is permanently changing. The complicated Slovak system of taxes and insurance in the long term is considered to be a factor which worsens the prospect of doing business in Slovakia.

The main objective of this paper was to bring scientific evidence that gender is one of the factors with a significant impact on the management of a company's administrative activities, on the perception of such administrative burdens as bureaucracy and, often, tax and legislative changes as one of the barriers faced by young entrepreneurs in the Slovak business environment. The paper uses data from research carried out in Slovakia in cooperation with the Association of Young Entrepreneurs of Slovakia, which is experienced with the group of young entrepreneurs. Their help in creating and distributing the questionnaire and provision of many valuable contacts and relevant information in this area was substantial.

In spite of the fact that the number of female entrepreneurs is significantly lower than that of their male counterparts, their different behaviour must be taken into account as an increase in their numbers in recent years is evident and the EU is trying to encourage their entry into the world of business.

Our results bring the following findings: young men and women consider different areas of bureaucracy excessive, and female entrepreneurs spend twice as much time monitoring legislative changes affecting the business environment, and almost twice as much time on administrative activities related to their business in comparison to their male counterparts. These findings are confirmed by the statistical evidence. This observation is important because a future increase in administrative burdens will bring further complications and women will spend yet more time on these activities, which is against the goal of the European Union - to make women's role in business easier.

Our research has some weaknesses. The most important are the facts that the respondents completed the questionnaire by email and we were unable to organize more detailed face-to-face interviews.

\section{Acknowledgement}

This research paper was funded from the project titled "Financing of young entrepreneurs and innovative companies with focusing on venture and private equity capital in Slovakia and EU" in the frame of the granting program of the Grant Agency of the Academic Alliance under the Grant agreement number 3/2016. 


\section{References}

1. Arnold, J., Nicoletti, G., \& Scarpetta, S. (2008). Product Market Policies, Allocative Efficiency and Productivity: a Cross-Country Analysis. Paris: OECD Economic department.

2. Barone, G., \& Cingano, F. (2008). Service Regulation and Growth: Evidence from OECD Countries. Retrieved January 1, 2016, from http://papers.ssrn.com/sol3/papers. cfm?abstract_id=1160183\&download=yes

3. Belás, J. et al. (2013). Řizení úvérového riz̨ika MSP. Management of credit risk of SME. Žilina, SK: Georg.

4. Belás, J., Bartoš, P., Ključnikov, A., \& Kozubiková, L. (2015a). Significant determinants of business environment in the segment of small and medium-sized enterprises. Scientific Papers Of The University Of Pardubice, 22(35), 5-17.

5. Belás, J., Ključnikov, A., Vojtovič, S., \& Sobeková-Majková, M. (2015b). Approach of the SME entrepreneurs to financial risk management in relation to gender and level of education. Economics and Sociology, 8(4), 32-42. doi: 10.14254/2071-789X.2015/8-4/2

6. Krasniqi, B.A. (2007). Barriers to Entrepreneurship and SME Growth in Transition: The case of Kosova. Journal of Development Entrepreneurship, 12(01), 17-94. doi:10.1142/ s1084946707000563

7. Bianco, M, \& Bripi, F. (2010). Administrative Burdens on Business Acitvities: Regional disparities. Giornale degli Economisti e Annali di Economica. 69(2), 37 - 79.

8. Constantinidis, C., Cornet, A., Asandei, S. (2006). Financing of women-owned ventures: The impact of gender and other owner- and firm-related variables. Venture Capital, 8(2), 133-57. doi:10.1080/13691060600572557.

9. Deininger, K. (2003). Land Policies for Growth and Poverty Reduction. New York: Oxford University Press.

10. Djankov, S, Mcliesh, C., \& Ramalho, R. (2006). Regulation and Growth. Economics Letters, 92, 395-401. oi:10.1016/j.econlet.2006.03.021

11. Djankov, S., La Porta, R., Lopez De Silanes, F, \& Shleifer, A. (2008). The Law and Economics of Slef-Dealing. Journal of Financial Economics, 88(3), 430-465. Available at: http://dx.doi.org/10.1016/j.jfineco.2007.02.007.

12. Fetisovová, E., Vlachynský, K., \& Sirotka, V. (2004). Finance of the Small and Medium-sized Enterprises. Bratislava: Edícia Ekonómia.

13. Field, E. (2006). Property Rights and Investments in Urban Slums. Journal of the European Economic Association, 3(2-3), 273 - 290. doi:10.1162/jeea.2005.3.2-3.279

14. Freel, M., Carter, S., Tagg, S., \& Mason, S. (2010). The latent demand for bank debt: Characterising discouraged borrowers. Small Business Economics, 1(1), 1-16. doi:10.1007/ s11187-010-9283-6

15. Garwe, D.K., \& Fatoki, O. (2012). The impact of gender on SME characteristics and access to debt finance in South Africa. Development Southern Africa, 29(3), 448 - 461. doi:10.1080/ 0376835X.2012.706040. 
16. Gamage, P. (2013). Determinants of access to bank finance for small and medium-sized enterprises: the case of Sri Lanka, Corporate Ownership and Control, 10(3), 341-321.

17. Irwin, D., \& Scott, J.M. (2010). Barriers faced by SMEs in raising bank finance. International Journal of Entrepreneurial Behavior and Research, 16(9), 245-259. doi:10.1108/135525 51011042816

18. Jappelli, T., Pagano, M., \& Bianco, M. (2005). Courts and Banks: Effects of Judicial Enforcement on Credit Markets. Journal of Money Credit and Banking, 37(2), 223 - 244. doi:10.1353/mcb.2005.0021

19. Jakubec, V., Sobeková Majková, \& M. Solík, J. (2012). Potreby mladých podnikatel’ov a prekážky y v ich podnikaní. [Needs and barriers of young entrepreneurs]. Bratislava: Združenie mladých podnikatelov.

20. Ključnikov, A., \& Junger, R. (2014). Barriers for foreign direct investments in Belarus: Case of business logistics. Proceedings of Carpatbian Logistics Congress 2013. Kraków: TANGER.

21. Královič, J., Fetisovová, E., \& Nagy, L. (2008). Rozvoj a finančná podpora malých a stedných podnikov v Európskej únii a na Slovensku [Development and Financial Support of SME in European Union and Slovak Republic]. Complex Solution of Theoretical and Application Problems Financing of Small and Medium-sized Enterprises in a Market Environment of the European Union. Plzeň: Západočeská univerzita v Plzni.

22. Majková, M. (2008). Možnosti financovania malých a stredných podnikov v SR [Possiblities of the SME financing in Slovak Republic]. Brno: Tribune.

23. Mama, A.T., \& Ewoudou, J. (2010). Who is credit constrained among denied or discouraged borrowers? Retrieved January 1, 2016, from //www.econrsa.org/papers/w_papers/wp199.pdf

24. Mijid, N. (2009). Gender, race and credit rationing of small businesses evidence from the 2003 survey of small business finance. Retrieved January 1, 2016, from // www.kauffman.org/research-andpolicy/kdfp/fellows.aspx

25. Ministry of Economy (2007). Better Regulation Agenda in Slovakia. Action Programme for reducing burdens in the Slovak republic 2007 - 2012. Retrieved January 1, 2016, from http://www. economy.gov.sk/navrh-politiky-vlady-sr-na-zlepsenie-podnikatelskeho-prostredia-v-sr$\mathrm{wdb} / 138424 \mathrm{~s}$

26. NADSME (2005). Readiness of Small and Medium-sized Enterprises to Non-bank Forms of Financing. Retrieved January 1, 2016, from http://www.sbagency.sk/sites/default/files/ pripravenost_msp_na_nebankove_formy_financovania.pdf

27. NADSME (2009). Annual Monitoring Report. Retrieved January 1, 2016, from http://www. sbagency.sk/sites/default/files/file/vyrocna_sprava_narmsp_2009.pdf

28. Paulík, J., Kombo, F., \& Ključnikov, A. (2015). CSR as a driver of satisfaction and loyalty in commercial banks in the Czech Republic, Journal of International Studies, 7(3), 111-126. doi: $10.14254 / 2071-8330.2015 / 8-3 / 9$

29. PAS (2008). A Survey on the Impact of the Financial Crisis on Business in Slovakia. Retrieved January 1, 2016, from http://alianciapas.sk/prieskum-o-dopadoch-krizy/

30. Petr, P. (2010). Condominiums and its Owners Associations. DANUBE: Law and Economics Review, (4), 41-48. 
31. PriceWaterhouseCoopers (2016). Paying taxes 2016. Retrieved from http://www.pwc.com/ gx/en/paying-taxes-2016/paying-taxes-2016.pdf

32. Roper, S., \& Scott, J.M. (2009). Perceived financial barriers and the start-up decision: An econometric analysis of gender differences using GEM data. International Small Business Journal, 27(2), 49-71. doi: 10.1177/0266242608100488

33. Sobeková-Majková, M. (2011). Ako financovat malé a stredné podniky [How to Finance SME]. Bratislava: Iura Edition.

34. Sobeková - Majková, M., Solík, J., \& Sipko, J., (2014). The Analysis of Chosen Business Obstacles and Problems with the Financing of Young Entrepreneurs in Slovakia, Economics \& Sociology, 7(3), 90 - 103. doi: 10.14254/2071-789X.2014/7-3/7.

35. SOPK (2009). Annual Report 2008. Retrieved January 1, 2016, from http://za.sopk.sk/ storage/dokumenty/Vyrocna_sprava_SOPK-2008.pdf

36. White, M.J., \& Berkowitz, J. (2004). Bankruptcy and Small Firms. Access to Credit. RAND Journal of Economics, 35, $69-84$.

\section{Contact information}

Ing. Aleksandr Ključnikov, Ph.D.

University of Business and Law

Department of Managerial Economics

Prague, Czech Republic

E-mail:kliuchnikov@gmail.com

Ing. Monika Sobeková Majková, PbD.

Paneuropean University

Faculty of Economic and Business

Bratislava, Slovakia

E-mail:monika.majkova@centrum.sk. 